\title{
GYEKYE'S MODERATE COMMUNITARIANISM: A CASE OF RADICAL COMMUNITARIANISM IN DISGUISE
}

\author{
Richard Ansah \& Modestha Mensah* \\ http://dx.doi.org/10.4314/og.v15i1.1
}

\begin{abstract}
Classical/radical communitarians argue that the community is morally supreme - whenever there is conflict between the interests of the individual and those of the community, the interests of the community come first. This is called the community primacy thesis. Kwame Gyekye, a reputable African philosopher, has argued otherwise. He believes that it is extreme and hyperbolic when radical communitarians emphasize the moral supremacy of the community and its values over the individual's (morality). He proposes moderate communitarianism, a theory, he believes, maintains the well-being of the community as a whole, and at the same time gives equal recognition to the individual and his or her rights. Moderate communitarianism balances responsibilities with rights. In this article, we argue that Gyekye's moderate communitarianism reecho's the radical version he criticizes and rejects.
\end{abstract}

Keywords: Communitarianism, Individual, Community, Rights, Duties/Responsibilities, Autonomy, Individual Good, Common Good.

\section{Introduction}

In Political Philosophy in general, and African Socio-Political philosophy in particular, the status of the individual and the community is very vital. Scholars in this field have invested time to uncover the actual role that both the individual and the community play as far as politics is concerned. Kwame Gyekye, a widely read Ghanaian philosopher, has done tremendous work to this effect. In his Tradition and Modernity: Philosophical Reflections on the African Experience, he articulates what he believes to be the actual relationship between the individual and the community. Moderate communitarianism has come to represent Gyekye's own position on the subject. Gyekye wants us to believe that his moderate communitarianism accords respect to individual rights, which he 
Ansah \& Mensah: Gyekye's Moderate Communitarianism:...

criticizes radical communitarians for failing to do. The thesis of this paper is that there is no substantial difference between Gyekye's moderate version and radical communitarianism. However, by this, we are not making a case for radical communitarianism.

In order to meet the demands of the thesis, this article is structured in three main parts. The first part is an exposition of radical communitarianism which Gyekye's version is a reaction to. The second part discusses Gyekye's moderate version. The final part presents arguments that support our position that Gyekye's moderate version is not substantially different from its radical counterpart.

\section{Radical Communitarianism}

Communitarianism is a theory that emphasizes the moral supremacy of the common good - the good of the community as a whole. A communitarian, thus, is someone who considers the community to be of central importance. The rationale for this is that the individual is a social being and can only flourish in the community. Early communitarian scholars who only emphasized the supremacy of the community without recourse to the individual's individuality and the rights that come with it are categorized as radical communitarians, proponents of which are JonhMbiti, Ifeanyi Menkiti, Alasdair MacIntyre, Charles Taylor, etc. Radical communitarianism is therefore interpreted as a theory that upholds the irrelevance of individual rights within the structure of an intimate and harmonious interaction among community members (Bond, 1996: 219). This version of communitarianism denies liberalism. Liberal rights are superfluous in a community characterized by shared values, where every member is already constituted by the community itself. Most importantly, the crux of radical communitarianism is spread over three main issues:

i. The individual is naturally a social being who is embedded in the community. This view is referred to as the inseparability thesis.

ii. The community is morally superior to the individual. In other words, common good (social responsibilities) is preferable to individual rights. This is what is meant by the primacy thesis. 
Ogirisi: a new journal of African studies, vol. 15, 2019

iii. Individual rights are superfluous in any community that is regulated by shared values, mutual understanding and love.

As far as the inseparability thesis is concerned, according to Plato, human beings' social nature is necessitated by economic needs. No individual is self-sufficient (The Republic 369b). The individual's social nature is designed by nature itself. The individual is naturally a dependent being. No individual is created to be able to provide for himself or herself, all his or her needs. Therefore, the natural inability of the individual to personally meet all his or her economic needs, without external support, compels him or her to seek the fellowship of others.

Inherent in the inseparability thesis is also the issue of the identity of the individual. Radical communitarians deny the liberal notion of the "unencumbered self", since the self is always defined by the community. McIntyre (1987, 1988) opines that the individual's life is understood only by looking at his or her actions within a story, a "narrative". From experience, we realize that one's narrative converges with the narratives of other people, who come to be part of one's own narrative. Thus, an understanding of one's self can be attained only in the context of the community that sets up the form and shape, as well as the circumstances and the background of these narratives. Consequently, our identities are constructed by the stories we tell ourselves, and our virtues and values are prescribed by the very nature of the specific social practices in which they function.

Judging from the above discussion, I believe that the basis for which radical communitarians make the claim about how individual identities are formed, stems from their claim that the community has ontological primacy over the individual (Menkiti, 1984). As a matter of fact, without the community, no individual can flourish. According to Gyekye, for radical communitarians such as Jomo Kenyatta, John Mbiti and IfeanyiMenkiti, the individual is wholly molded and constituted by his or her immediate community (Gyekye, 1997: 36-37). Menkiti particularly notes that:

It is the community which defines the person as person, not some isolated static quality of rationality, will, or memory....in the African 
Ansah \& Mensah: Gyekye's Moderate Communitarianism:...

understanding the human community plays a crucial role in the individual's acquisition of full personhood (Menkiti, 1984: 172, 179).

This radical communitarian view, we believe, proceeds from the assumption that the welfare, values and goals of the community are supreme. These values and goals of the community are as well perceived as overriding as far as morality and social justice are concerned. In the quotation that follows, we see McIntyre affirming the identity claim made by Menkiti concerning how the individual's identity is completely determined through his or her communal interactions;

... the story of my life is always embedded in the story of those communities from which I derive my identity. I am born with a past; and try to cut myself off from the past, in the individualist mode, is to deform my present relationships. The possession of a social identity coincides. Notice that rebellion against my identity is always one possible mode of expressing it (MacIntyre, 1984: 211).

An analysis of the quotation above reveals that an individual's experiences and interactions in a culture or society are responsible for giving the individual his or her identity. These experiences and the individual's identity are so intimate that it is impossible for the individual to detach himself or herself from such experiences.

Moving on to the issues of the moral supremacy of the community over the individual, and the superfluity of rights in a community regulated by love and shared values, radical communitarians uncompromisingly support the community and responsibilities in the case of a moral clash between the individual and the community on rights and responsibilities. The community is morally prior to the individual and ought to be protected even if such protection will hinder individual rights to liberties (Gyekye, 2003: 36; Etzioni, 2003: 1; Sandel 1983: 1). For radical communitarians, rights can never be morally higher than the community. The word "community" naturally renders the word "rights" unnecessary. This is why radical communitarianism is also described as the family 
model communitarianism. A community regulated by shared values, mutual understanding, spirit of fellow feelings and love, does not need rights at all. In such a community, rights are redundant values and this is why Sandel says that the liberal priority of rights is an error. The liberal view that "the right is prior to the good (that individual rights cannot be sacrificed for the sake of the general good) is mistaken" (Sandel, 1992: 73). The individual's rights only exist because the community exists (Gyekye, 1997:35). And because radical communitarians perceive the individual as naturally, socially, culturally and historically tied to others in the community, the community should be honored by the individual because the same community nurtures him or her (Gyekye, 1997: 36). The natural bond between the individual and the community,therefore, morally compels the former to respect communal values such as "responsibility, mutual aid, caring for others, interdependence, solidarity, reciprocal obligation and social harmony" (Gyekye, 2003: $35)$.

In effect, the case for radical communitarians is that since individuals are, naturally, social beings and depend on their interactions with other members of the community to flourish, and since the individuals' identities are formed in the course of these interactions, the community ought to always come first, and the individual second - the individual is second to the community.

\section{Gyekye's Moderate Communitarianism}

The motivation for this version of communitarianism, according to Gyekye, is to show that individual rights and by extension individuality, are recognized in a communitarian framework. Gyekye believes that this is what the radical version has failed to realize, thus making the theory difficult to support (Gyekye, 1997: 38). Therefore, Gyekye's moderate communitarianism recommends a readjustment of radical communitarianism. He says his version should be preferred to the radical one because his version accords "... equal moral status to both the community and the individual..." (Gyekye, 1992: 107; 1997: 41; 2004: 58), and the implication is that the individual is allowed room to exercise his or her rights.

Gyekye's moderate communitarianism is built on three main tenets: the social and rational nature of the individual, the recognition of individual rights, and the moral supremacy of the community. The 
Ansah \& Mensah: Gyekye's Moderate Communitarianism:...

details of these tenets, Gyekye believes, make his theory more acceptable than the radical version.

Gyekye claims that the community plays a vital role in the formation of the individual's personhood or identity. This claim emanates from his belief that a person when born finds himself or herself, not in isolation, but among other individuals and this establishes the social or relational nature of a person. Per the inherently relational or social nature of the individual, Gyekye's communitarianism sees the community as a reality in itself and not as a mere association of individuals. A community, in this context, is a group of persons linked by interpersonal bonds, which are not necessarily biological, where members consider themselves primarily as members of a group and who share common goals, values and interests. For Gyekye, members of the community may be bound together by other factors, such as the common good and shared values, instead of biological ties (Gyekye, 1997: 56). Gyekye (1992: 104) goes on to argue that "an individual human being is born into an existing human society and, therefore into a human culture, the latter being the product of the former". By this, Gyekye's intention is to portray the relational and the social features of the person in the context of the cultural community. It thus follows that the idea that a person is born into an existing community supports the view that a person is by nature a communal being and therefore community life is not optional.

Regarding the individual's identity, Gyekye explains that a person comes to know who he or she is in the context of his or her relationships with others in such communities (Gyekye, 1997:43). In this regard, Bell (1993) further reinforces Gyekye's position, by indicating the implications of such a communitarian concept of community. For him, "constitutive communities" define the sense of who we are and provide a large background of our being in the world of thinking, acting and deciding. A similar view is expressed in Bell (1995: 97) when we are informed that we can answer the question of what these "constitutive communities" are by asking a question of ourselves: Who are you? The answer will certainly include: family name, nationality, language, culture and religion - all of which derive from community.

To further explain what he means by the community gives the individual his or her identity, Gyekye (1997: 43) says, 
The community constitutes the context for the creation and development of a person's identity ... for, a person comes to know who she is in the context of relationships with others, not as an isolated, lonely star in a social galaxy ... a person's identity derives, at least in part, from a cultural context, that is, a community.

The quotation above, in our understanding, is portraying the community as the framework within which the individual's identity is formed. This identity is formed by each individual going through the process of social relationships with others. Gyekye further intimates that the social context that hosts the individual's identity could deny the individual the status of personhood if the individual fails to exhibit certain moral virtues. Consider Gyekye when he says:

Now, the moral significance of denying personhood to a human being on the grounds that his actions are known to be dissonant with certain fundamental norms or that he fails to exhibit certain virtues in his behavior is extremely interesting for communitarianism. Personhood, in this model of humanity, is not innate but is earned in the ethical arena: it is an individual's moral achievement that earns him the status of a person. Every individual is capable of becoming a person inasmuch as he is capable of doing good and should therefore be treated (potentially) as a morally responsible agent" (Gyekye 1997: 51-52).

The above quotation sums up Gyekye's idea of the communal constitution of the individual. The social interactions among individuals in a community are the grounds for couching out the individual's identity or personhood. Inherent in these social relationships are the exhibition of moral virtues, the absence of which an individual may not qualify as a person. This seems to suggest that as far as the communal constitution of the individual is concerned, personhood is achieved, and so far as something is achievable, it goes to say that one can as well fail at achieving it. For 
Ansah \& Mensah: Gyekye's Moderate Communitarianism:...

Gyekye then, in the community context where morality is the yardstick for determining one's identity, the principles of the common good on the one hand and the community of mutuality, reciprocity and responsibilities on the other hand, are vital.

We can see the similarity in content spewed by both Gyekye and the radical account of the individual. They both emphasize the role that the community plays when it comes to defining who a person is. Yet, Gyekye is quick to add that the natural sociality of the individual, the organic character of the relations between individuals and the relevance of the community to the total wellbeing of the individual, can give rise to a hyperbolic and extreme view of the functional and normative status of the community. For him, one could err in concluding that the community wholly constitutes the individual. This is because there are other features of the individual, features that are not created or generated by the community; these features emanate solely from the individual and insofar as these features are defining characteristics of one's identity, personhood is only partially defined by the community. What are these other features Gyekye talks about?

On page 47 of Tradition and Modernity, Gyekye characterizes the individual as an inherently communal being, embedded in a context of social relationships and interdependence, and never an isolated individual. However, the individual possesses other attributes, such as rationality and the capacity for evaluation and making moral judgments that may also be said to constitute his or her nature.Gyekye (1997:47-48) argues:

The individual is by nature a social (communal) being, yes; but he is, also by nature, other things as well; that is, he possesses other attributes that may also be said to constitute her nature. The exercise or application or consideration of these attributes will whittle down or delimit the "authoritative" role or function that may be ascribed to, or invested in, the community. Failure to recognize this may result in pushing the significance and implications of the individual's social nature beyond their limits, an act that would in turn result in investing the community 
with an all-engulfing moral authority to determine all things about the life of the individual.

He calls these attributes a "mental feature". By this mental feature, Gyekye means that the individual aside being a communal being, is also a rational being; has a moral sense and capacity for virtue, and thus evaluates and makes moral judgments. What these attributes amount to is the individual's capacity for choice, the possession of autonomy. The possession of autonomy is biologically given and not created by the community. Yes, individuals are social by nature but they are as well rational by nature. Gyekye's argument then is that if the mental feature of the individual plays a vital role in the formation and execution of his or her goals or plans, as does the community, then it cannot be argued that the individual is wholly constituted by social relationships (Gyekye, 1997: 53). It can only be partial. This conclusion made by Gyekye is backed by the fact that within the communal or social framework that individuals achieve their goals and plans, individuals who participate in the shared values and practices may find that portions of these "cultural givens are inelegant, undignified, or unenlightened and would thoughtfully want to question and re-evaluate them" (Gyekye, 1997: 54). It is through these questioning and re-evaluations that communal goals and values may be affirmed, amended or totally rejected to give way to a better alternative. This process, for Gyekye, is proof that the individual is not totally enmeshed into the community and that he or she can actually wriggle himself or herself out of the community and assert an individuality of a sort. The individual is separable from the community.Thus, contrary to the radical communitarian communal constitutive conception of the individual, Gyekye is of the view that the individual is only partly constituted by the community (Gyekye and Wiredu, 1992: 106).

On the issue of rights, Gyekye rejects the line radical communitarians such as Maclntyre, Sandel, Taylor, and Walzer draw between the individual good and the common good, rights and responsibilities. Gyekye rejects radical communitarians' treatment of rights as secondary values (Gyekye, 1992: 113). For him, rights belong primarily and irreducibly to the individual, for they (rights) are a means of expressing an individual's talents, capacities, and identity. Gyekye's argument for the recognition of rights rests on his 
Ansah \& Mensah: Gyekye's Moderate Communitarianism:...

understanding that if his moderate communitarianism acknowledges individual autonomy, then this acknowledgement must involve the recognition of rights, for

... a communitarian denial of rights or reduction of rights to a secondary status does not adequately reflect the claims of individuality mandated in the notion of the moral worth of the individual. Such a claim would be extreme and would be at variance with the moderate communitarian view that I think is defensible (Gyekye, 1997: 62).

Gyekye thus argues for the recognition of rights in the arguments that follow. First of all,

Communitarianism cannot disallow arguments about rights which may in fact form part of the activity of a self-determining autonomous individual possessed of the capacity for evaluating or reevaluating the entire practice of his community. Some of such evaluations may touch on matters of rights, the exercise of which a self-determining individual may see as conducive to the fulfillment of the human potential, and against the denial of which he may raise some objections (Gyekye, 1992: 6263).

The import of Gyekye's view is that the individual is both a social and rational/autonomous moral agent. By being a rational agent, he or she possesses the capacity and wherewithal to make independent moral decisions and choices, through the processes of re-evaluation and assessment. When an individual is evaluating a particular communal value or practice, for example, he or she may consider how such a value infringes or not on the rights of individuals to whom these values and practices are applied. The individual doing the re-evaluation then may demand that values or practices that are inimical to the overall progress and development of the community should be jettisoned. In view of this capacity, the exercise of rights by the individual does not parochially aim at the 
Ogirisi: a new journal of African studies, vol. 15, 2019

individual good alone but it equally aims at enhancing the overall community good.

Gyekye further makes a case for the recognition of rights by arguing that:

The respect for human dignity, a natural or fundamental attribute of the person which cannot, as such, be set at nought by the communal structure, generates regard for personal rights. The reason is that the natural membership of the individual person in a community cannot rob him of his dignity or worth, a fundamental and inalienable attribute he possesses as a person (Gyekye, 1997:63).

We observe here that Gyekye sees the individual as intrinsically valuable and so needs to be accorded respect and dignity. The value of human dignity can be argued for from both theistic and nontheistic perspectives. For theists, the individual is seen as one who has a soul as part of his or her ontological make up. The soul is believed to be a divine spark in human beings, evidence that God created human beings. Gyekye (1992: 114, 1997: 63) thus quotes an Akan proverb "All human beings are children of God; no one is a child of the earth" to support the theistic argument. However controversial the concepts of God and soul are, and how the soul translates to become the connection human beings have with the divine, let us for now accept that the assumptions are correct. The possession of a soul then requires that each individual be treated with dignity and respect.

From a non-theistic perspective, reflections on the nature of human beings have influenced some scholars to argue that human dignity is grounded on human capacity for moral autonomy. This leads Kant to say in his categorical imperative that "Act in such a way that you always treat humanity, whether in your own person or in the person of any other, never simply as a means, but always at the same time as an end" (Kant, 1959: 58).

Now where is all this pointing to with regards to Gyekye's recognition of rights? Gyekye wants us to believe that if a communitarian theory respects individual worth, dignity and rights, this respect translates into the overall good of the community that 
Ansah \& Mensah: Gyekye's Moderate Communitarianism:...

recognizes these rights. This is because the notion of human dignity and worth, for him, generates and compels the recognition of innate or natural rights. Thus according to him:

At both the theoretical (conceptual) and practical levels, communitarianism cannot set its face against individual rights, for implicit in communitarianism's recognition of the dual features of the self as an autonomous, self-determining entity capable of evaluation and choice and as a communal being, is a commitment to the acknowledgement of the intrinsic worth of the self and the moral rights which can be said necessarily to be due to it. The recognition by communitarian political morality of individual rights is a conceptual requirement. At the practical level communitarianism must realize that allowing free rein for the exercise of individual rights - which obviously includes the exercise of the unique qualities, talents and dispositions of the individuals ... will enhance the cultural development and success of the community. If communitarianism were to shrug off individual rights, it would not only show itself as an inconsistent moral and political theory, but in practical terms would also saw off the branch on which it was going to sit (Gyekye 1992: 115, 1997: 64).

As mentioned above, it is morally and pragmatically important for communitarianism to recognize rights because the exercise of these rights will inure to the success of the community. The reason is that if individuals exercise their unique qualities, talents and visions and these qualities bring more fortunes to the community, then allowances should be made for such individual rights.

Having made his case for the recognition of rights, Gyekyecautions that we must not lose sight of responsibilities that foster the good of the community. For, responsibility, "a caring attitude or conduct that one feels one ought to adopt with respect to 
the well-being of another person or persons" (Gyekye, 1997: 66) trumps over the exercise of rights. For him, "in the communitarian political morality, priority will not be given to right if doing so will stand in the way of... a more preferable goal of the community" (Gyekye, 1992: 116). Also, while the communitarian structure would not have a "fetishistic" attitude toward individual rights, it would certainly have one toward duties that individuals have toward members of the community (Gyekye, 1992: 116). Gyekye says though his theory is not opposed to individual rights, it will consciously give equal attention to communal values, all (or some) of which it may regard as overriding, and so communitarianism cannot be expected to be obsessed with rights (Gyekye, 1997: 65). In simple terms, when individual rights (which include responsibilities) clash with those of the community, the latter always override the former. Again, whereas Gyekye's communitarianism discourages the insistence on individual rights, it certainly encourages the insistent pursuit of duties and responsibilities by the individual to promote the common good.

\section{Radical Communitarianism in Disguise}

Gyekye's take on the definition of the individual's personhood is a good point to begin our analyses with.Gyekye, earlier, rejects the radical communitarian claim that personhood is achieved and that one can fail at it. For him, socio-economic status, not personhood, is what is achieved and one can fail at (Gyekye, 1997: 49-51). Having said this, Gyekye later commits himself to this same claim for which he criticizes radical communitarians. This is evident when he says that:

Now, the moral significance of denying personhood to a human being on the grounds that his actions are known to be dissonant with certain fundamental norms or that he fails to exhibit certain virtues in his behaviour is extremely interesting for communitarianism. Personhood, in this model of humanity, is not innate but is earned in the ethical arena: it is an individual's moral achievement that earns him the status of a person. Every individual is capable of becoming a person inasmuch as he is 
Ansah \& Mensah: Gyekye's Moderate Communitarianism:...

capable of doing good and should therefore be treated (potentially) as a morally responsible agent"(Gyekye 1997: 51-52).

Two points can be deduced from the quotation above. First, Gyekye explicitly commits his definition of personhood to moral achievement in the same way that radical communitarians do. Radical communitarians maintain that personhood is acquired, and not a given. In the same way, Gyekye maintains that the communitarian conception of personhood is not innate but acquired in the moral arena. By accepting that personhood is acquired, Gyekye appears to be raising contradictory arguments. At this point, it is not clear how different Gyekye's understanding of personhood is from that of radical communitarians.

The second point that is deduced from the quotation is Gyekye's admission that the community can deny an individual his or her personhood on the grounds that certain communal virtues and norms are not possessed and observed respectively. Gyekye is however quick to add that the individual who is denied personhood still qualifies as a human being by virtue of his or her rational or autonomous character. We realize here that Gyekye distinguishes between a person and an individual. While a person is one who exhibits moral virtues and so is in sync with the community, an individual is one who is detached from the community and so fails at personhood. Gyekye says that even though the individual is not a person, he or she ought to be respected and treated as such because he or she is still a human being (Gyekye 1997: 50). In line with Matolino's (2009) observation, I believe thatGyekye's distinction between a person and an individual does not reinforce his argument. Gyekye is indeed right that the individual who fails at personhood is still a human being and so should be treated accordingly. Yet, the issue under investigation concerns personhood and not humanity as such. That radical communitarians do not elaborate on what becomes of the individual who fails at personhood does not necessarily make their account all that different from Gyekye's. We do not see what could prevent radical communitarians from also saying that such an individual is still a human being. So far as Gyekye claims, just like radical communitarians do, that morality is the key ingredient of personhood and that one who does not have 
Ogirisi: a new journal of African studies, vol. 15, 2019

this ingredient fails at it, Gyekye is not very different from a radical communitarian. In other words, Gyekye accepts the social embeddedness of the individual, just like radical communitarians do. It is noteworthy; however, that Gyekye's acknowledgement of the rational or autonomous feature of a person, in addition to his or her social character, is a comprehensive account of the constitution of a person. Radical communitarians fail to recognize this inalienable fact about the individual and therefore, are not able to present a comprehensive and robust account of a person like Gyekye does.

Another interesting point Gyekye makes that is worthy of analyses is his principle of equal moral standing of the individual and the community. In other words, individual rights and duties/social responsibilities are recognized in equal measure (Gyekye, 1992: 107; 1997: 41; 2004: 58). This is what, according to Gyekye, radical communitarianism fails to do and as such, his success makes his version moderate. Yet, with reference to Oyowe's (2013b: 138) critique, Gyekye's principle is problematic from the onset. The problem lies in Gyekye's understanding of and response to the source of the individual - community controversy. Gyekye's response to the individual - community controversy misconceives the source of the dilemma. This is seen from what his moderate communitarianism is meant to do - to acknowledge, while still retaining its communitarian orientation, "the intrinsic worth and dignity of the individual human person"(1997: 40). It is also to recognize "individuality, individual responsibility and effort", and in his assertion that "... no human society is absolutely communal or absolutely individualistic" (1997: 41), as though this point was ever in contention. The fact of the matter is that there are communitarian features in the most individualistic societies and vice versa. Those who assert either the communal or individual priority thesis would concede this point. The only difference between the two sides of the debate is a matter of emphasis. Communitarians will, therefore, emphasize communitarian features and claim that individualist features are only derivative. Similarly, individualists will also regard the communitarian features as derivative and not primary. In fact, radical communitarians do not deny that there are features of human society that can be broadly characterized as individualistic. If this is true, then a metaphysics, like Gyekye's own that merely requires the recognition of individuality in the communitarian scheme misses the 
Ansah \& Mensah: Gyekye's Moderate Communitarianism:...

point. And in making this his central concern, Gyekye rather assumes that the real controversy was about the failure to recognize individuality; which is not the case.

The source of the controversy regarding the tension between the individual and the community is that both the individual and the community are considered to be fundamental and so the treatment of the two entities requires the recognition of their fundamentality. Now, if the source of the controversy was not merely about recognition, perhaps it was about equal recognition. Part of Gyekye's point is that the individual and the community should be recognized equally. In this way, Gyekye hopes that his metaphysics would take us beyond the simple individual - community priority dichotomy. He also wants to say that metaphysical equality has some merits over priority - it holds better promise in resolving the individual - community dilemma (Gyekye, 1997: 76). But herein lies the puzzle - the original source of the dilemma is precisely due to assigning equal weight to the demands of individuality and communality. How then can a theory with the same fundamental principle of equal recognition take us beyond the original problem? Our view is that it cannot. Such a theory which promises to maintain its communitarian commitment will surely place more value on the community and social responsibilities, to the disadvantage of the individual and his or her rights.

To make clearer how the principle of equality flaws Gyekye's theory, let us consider the contemporary issue of the rights of gays and lesbians, we are told, living in many contemporary African communities. We should also bear in mind that these communities have a well-defined conception of what constitutes the good, including acceptable sexual options that are consistent with certain highly prized collective values. Such values spring from a recognition of the place and role of the family, and important kinship relations, in forging a sense of group membership. Metz (2007) says that "Many African people think there is some strong moral reason to extend familial relationships by finding a (heterosexual) spouse and having children. ...". He goes on to explain that this goes beyond the simple obligation to care for one's children or remain faithful to one's spouse; it is "the stronger claim that one has some obligation to wed and procreate in the first place" (Metz, 2007: 327-328). The point is that the idea of a collective good incorporates preferences 
and values closely aligned with and propagative of family and kinship relations. In particular, it includes a clear preference for heterosexuality.

Elsewhere, Bristow (2010: 247) observes that "same-sex desire can be threatening to those institutions ... such as family ... that assume that heterosexuality is a natural, as opposed to cultural phenomenon". By publicly questioning the consensus and the idea of the common good that legitimize the "naturalness" of heterosexual relations, and traditional notions of family, the open acknowledgment and practice of homosexuality threatens the very basis of a communitarian ethic. Thus, it is not trivial that homosexuality is one of the most intensely disputed and divisive issues in contemporary Africa and one that clearly pits the demand for individual liberties against a well-defined and substantive conception of communal good.

The point hereby made is how might a moral agent (who is applying Gyekye's theory) cope with the question of the rights of gays and lesbians in contemporary Africa, where a robust conception of the common good is equally regarded, as do individual rights? It appears that equally recognizing the rights of gays and lesbians, on the one hand, and the specific obligation to procreate, which is born out of a conception of the common good, on the other hand, would not provide any real guidance to moral agents and legislators. Nor is it entirely clear what a politics of consensus would amount to on such a deeply divisive matter. In either case, a moral agent or legislator could not rely on the principle of equal regard; acting would ultimately presuppose some kind of ordering of values and subsequent trade-off, which is contrary to the principle of equal regard. Since the injunction to equally regard individual rights and communal good cannot provide any real guidance, it is difficult to work with Gyekye's principle.

However, a choice has to be made. The dilemma ought to be resolved and Gyekye himself accepts this. Gyekye responds that individual rights that are private in nature ought to be allowed. However, if there is evidence that the expression of such rights affects other members of the community, then such rights should be banned since they do not promote the good of the community (Gyekye, 1997: 64). How might we apply Gyekye's caveat to the issue about gay and lesbian rights? On the one hand, we can interpret 
Ansah \& Mensah: Gyekye's Moderate Communitarianism:...

Gyekye to mean that lesbians and gays can express their rights only in the confines of their rooms where there are no third parties. This is problematic because an individual's rights can only be fulfilled by third parties through their actions or inactions. Third parties are obliged to fulfill other people's rights because of the intrinsic worth of these rights. The point we are arriving at is that it is not in the nature of rights to be exercised or expressed privately; otherwise they would not be rights at all. Therefore, anyone who promises to recognize rights cannot insist that they be exercised privately, like Gyekye seems to suggest. It appears to me that Gyekye treats the exercise of such rights with spite and the expression of such rights is hypocritical. But rights are valuable. Wherein then lies their value if rights cannot be expressed openly?

On another interpretation of Gyekye's moderate communitarianism, gay and lesbian rights that are expressed in public ought to be suspended or banned since such expressions will affect the community. Now for a theory that is built on the principle of equal moral standing of both the community and the individual, the suspension of individual rights in cases of clash disregards and contradicts the principle itself. What is more, the problematic and impracticality of Gyekye's equality principle relates directly to his treatment of individual rights. Gyekye criticizes radical communitarians like Michael Sandel, Charles Taylor and Ifeanyi Menkiti that their communitarian claims deny rights or reduce rights to a secondary status and this does not adequately reflect the claims of individuality mandated in the notion of the moral worth of the individual (Gyekye, 1997: 61, Famakinwa, 2010b). Gyekye goes further to say that these communitarians claim that "the politics of rights should be given up and replaced with the politics of the common good" (Gyekye, 1997: 62). He says such claims are extreme and would be at variance with the moderate communitarian view which he thinks is defensible. He believes that his moderate version is defensible because the "mental feature" which is constitutive of the individual is a commitment to the expression of rights. As individuals showcase this mental feature through their self-assertiveness, capacity for re-evaluation, etc., individual rights are exercised. Furthermore, Gyekye argues that his version recognizes human worth and dignity and this recognition translates to the respect for individual rights. This is because the notion of 
human dignity and worth, for him, generates and compels the recognition of innate or natural rights. Thus, he is convinced that his theory recognizes rights but radical communitarianism does not.

In our opinion, Gyekye's conclusion that radical communitarians reject rights is misleading. In fact, radical communitarians do recognize rights only that they (radical communitarians) advocate for the limitedness of rights (Famakinwa, 2010b). Gyekye himself says that respect for individual worth and dignity is accepted from both theistic and non-theistic perspectives. The implication is that radical communitarians may respect individual worth and dignity, which they actually do. Now if the respect for individual worth and dignity generates and compels the recognition of innate or natural rights, then insofar as radical communitarianism respects individual worth and dignity, it equally recognizes natural rights. Basic rights such as rights to life, rights to freedom of speech, right to justice, etc. are not rejected in the radical communitarian scheme of things. Wiredu's (1996) account of human rights from the Akan perspective is particularly instructive. Wiredu informs us that in traditional Akan society, a new-born child in his or her fragile and helpless state requires the attention and care from family members in order to survive. As the child grows, the obligation falls on members of his or her family or clan to avail resources that will enable the child to be independent and cater for himself or herself. This is where rights to property such as land, come in. As the child matures and is affected by decisions taken in his or her community, he or she has the right to participate in political matters that affect his or her well-being. It is clear from the progression that rights are not rejected in communitarian societies whether radical or moderate. Gyekye's recognition of them does not make his argument very convincing since the rights he recognizes have always been there in radical communitarianism.

Furthermore, Sandel's critique of liberalism does not amount to the rejection of rights. Rather, he advocates that rightsbe limited. Similarly, Taylor's unrestricted communitarianism, like the moderate communitarianism of Gyekye, recognizes the individual's capacity for autonomy though such a capacity can only flourish in a human community (Taylor, 1992a: 33). In Spheres of Justice (1983), Walzer argues the individual's right to community membership. For him, membership of the community is the primary social good 
Ansah \& Mensah: Gyekye's Moderate Communitarianism:...

shared among members. Membership, for natural members, is a right. Individuals born into the community by parents who are also members have a right to membership (Famakinwa, 2010b: 72).

Interestingly, after criticizing the radical communitarian primacy thesis, Gyekye offers a startling rendition of how his moderate communitarian society really views individual rights when he says:

With all this said, however, it must be granted that moderate communitarianism cannot be expected to be obsessed with rights. The reason, which is not far to seek, derives from the logic of the communitarian theory itself: it assumes a great concern for values, for the good of the wider society as such. The communitarian society, perhaps like any other type of human society, deeply cherishes the social values of peace, harmony, stability, solidarity, and mutual reciprocities and sympathies (Gyekye, 1997: 65).

In the case of a moral clash between the rights of the individual and these communal values, the communal values ought to take precedence over the rights of the individual. Gyekye's primacy thesis is, like that of Sandel (1983), Taylor (1992a) and Menkiti (1984), supported by the social nature of the individual. The individual's relational character defined by his or her natural sociality "immediately makes her naturally oriented to other persons with whom he or she must live" (Gyekye, 1997: 67). It can be deduced that Gyekye's view endorses Sandel's idea of limiting rights and Taylor's view that rights can only flourish in the community. Both Gyekye and radical communitarians are not obsessed with rights and they value harmony, peace, stability and solidarity. Where then is the gap between Gyekye and radical communitarians?

More significantly, Gyekye rather closes any gap that may possibly exist between him and radical communitarians when he insists that:

Individual rights, the exercise of which is meaningful only within the context of human society, must therefore be matched with social responsibilities. In the absence of the display of 
sensitivity to such responsibilities, the community will have to take the steps necessary to maintain its integrity and stability. The steps are likely to involve abridging individual rights, which, thus, will be regarded by the moderate communitarian as not absolute, though important (Gyekye, 1997: 65).

This is how far Gyekye, just like any other radical communitarian, would go should there be any anti-social activities by individuals. He then goes on to urge that the exercise of rights must be within an appropriate social context and that it is legitimate that concerns be raised about that social context. It is not clear what those conditions would be. However, what is clear is that these two positions approach each other when they are contrasted with the view that the notion of a right is something inalienable or unbridgeable (Matolino, 2009: 169). For a theory that seeks to balance rights and responsibilities because both the community and the individual are equally important, it is difficult to conceive that rights will constantly be abridged to serve the purpose of the community. We do acknowledge the fact that rights can be categorized in order of importance with some rights taking precedence over others. For example, the right to life should be prioritized over right to freedom of worship. However, it is one thing to say that rights need to be balanced with one another. But if they are all subject to being waived, then in what respect are they rights at all?

Still on Gyekye's endorsement of the radical claim about the moral supremacy of the community over the individual, Famakinwa (2010a: 73) has argued that Gyekye's recognition of rights is not for the sake of the individual himself or herself but for the sake of the community. We agree with Famakinwa on the view expressed above because an analysis of Gyekye's own words below projects the understanding that the individual is valued basically because he or she is valuable to the community. Gyekye could not be any clearer when he states:

At the practical level, communitarianism would realize that allowing free rein for the exercise of individual rights, which obviously includes the exercise of the unique qualities, talents and 
Ansah \& Mensah: Gyekye's Moderate Communitarianism:...

dispositions of the individual, will enhance the cultural development and success of the community ... Though rights belong primarily to the individuals, insofar as their exercise will often directly or indirectly, be valuable to the larger society, they ought to be recognized by the communitarian theory (Gyekye 1997: 64).

From the quotation above, we realize that Gyekye recognizes rights for the reason that these rights will benefit the community in the long run. The question that arises is; what happens to rights, the exercise of which does not benefit the community? Should such rights be recognized? It seems that upon an interpretation of Gyekye's words, such rights will not be recognized. What follows is that if rights are subject to being traded off, then in virtue of what are they primary values? Has Gyekye not treated rights as secondary values, the same treatment of which he criticizes radical communitarians? A rejection of this, by Gyekye, we hold shall be self contradictory.

\section{Conclusion}

Indeed the individual and the community are fundamental entities whose value and worth cannot be downplayed. It is precisely because of this worth that socio-political philosophers who set out to articulate the relationship between the two, do so cautiously. Similarly, it is owing to this same fact that radical communitarianism is attacked for placing undue emphasis on the community to the neglect of the individual and his or her rights in the case of conflict of interests. Gyekye himself recognizes this error on the part of radical communitarians and criticizes them for it. The real question is, does Gyekye's own solution to the problem suffice? Does Gyekye's moderate communitarianism indeed save the individual from the clutches of the community or does it rather reinforce the radical communitarian stance? We have argued in this article that the latter is the case.

First, Gyekye's analyses of personhood are not very different from that of radical communitarians which he criticizes. Gyekye makes the point that an individual could be denied personhood in the event that he or she fails to attain certain moral 
Ogirisi: a new journal of African studies, vol. 15, 2019

virtues. If this is the case, then Gyekye is implying that the personhood of the individual is determined by the community, and insofar as one can fail at it, the reasoning is that personhood is acquired. Radical communitarians say the same thing.

Second, we have argued in this article that the fundamental principle of equal moral standing of the individual and the community which underlies Gyekye's theory is flawed for two reasons. The first is that Gyekye misreads the original source of the dilemma as far as the individual -community debate is concerned. The second reason is that the principle is impractical for it ignores the conflict between the interests of the individual and the community.

Third, Gyekye's promise to recognize individual rights in equal proportion as he does social responsibilities is unsuccessful. $\mathrm{He}$ ends up treating rights as secondary values just as radical communitarians do, by prioritizing the interest of the community over individual rights in cases of clashes between the individual and the community.

Finally, where Gyekye accommodates individual rights, it is precisely for the sake of the community at large, and not for the individual himself or herself in particular.

\section{*Richard Ansah}

Senior Lecturer, University of Cape Coast,

Cape Coast, Ghana

Email: ransah@ucc.edu.gh

\section{*Modesta Mensah}

Senior Research Assistant, University of Cape Coast, Cape Coast, Ghana 
Ansah \& Mensah: Gyekye's Moderate Communitarianism:...

\section{References}

Bell, D. (1995). "A Communitarian Critique of Authoritarianism", Society, 32(5): $38-43$.

Bell, D. A. (1993).Communitarianism and its Critics. Oxford: Oxford University Press.

Bond, E. J. (1996). Ethics and Human Well-Being. Cambridge: Blackwell Publishers.

Bristow, J. (2010). Homophobia. In M. Payne and J. Barbera (Eds.), Dictionary of Cultural and Critical Theory (pp. 335). Oxford: Basil Blackwell Publishers.

Etzioni, A. (2003). Communitarianism.In K. Christensen and D. Levinson. (Eds.), Encyclopedia of Community: From the Village to the Virtual World, Vol. 1 (pp. 224-228). Sage Publications.

Famakinwa, J. O. (2010b). How Moderate is Kwame Gyekye's Moderate Communitarianism? Thought and Practice, 2(2), 65-77.

Famakinwa, J. O. (2010a) The Moderate Communitarian Individual and the Primacy of Duties. Theoria. 76:152-166.

Gyekye, K. (2004). Beyond Cultures: Perceiving a Common Humanity. Washington D. C.: The Council for Research in Values and Philosophy.

Gyekye, K. (2004). Beyond Cultures: Perceiving a Common Humanity. Washington D. C.: The Council for Research in Values andPhilosophy.

Gyekye, K. (2003). Person and Community in African Thought.In P. H. Coetzee and A. P. J. Roux (Eds.), The African Philosophy Reader (2nd ed.), (pp. 297-312). New York: Routledge. 
Ogirisi: a new journal of African studies, vol. 15, 2019

Gyekye, K. (1997). Tradition and Modernity. New York: Oxford University Press.

Gyekye, K. \&Wiredu, K. (Eds.). (1992). Person and Community: Ghanaian Philosophical Studies. Washington, D.C.: Council for Research in Values and Philosophy.

Kant, I. (1959). Foundations of the metaphysics of morals. Lewis White Beck (Trans.) New York, NY.

MacIntyre, A. (1987). The Idea of an Educated Public. In Education and Values: the Richard Peters Lectures. London: London Institute of Education.

MacIntyre, A. (1988). Whose Justice? Which Rationality? Notre Dame, IN: University of Notre Dame Press.

Matolino, B. (2009). Radicals versus moderates: A critique of Gyekye's moderate communitarianism. South African Journal of Philosophy, 28(2), 160-170.

Menkiti, I. A. (1984).Person and Community in African Traditional Thought. In R. A.Wright (Ed.), African Philosophy: An Introduction. New York: University Press of America.

Metz, T. (2007).Towards an African Moral Theory. The Journal of Political Philosophy. 15:331-34.1.

Oyowe, O. A. (2013b). Personhood and Human Rights: A Critical Study of the African Communitarian and Normative Conception of the Self (Doctoral Thesis, University ofKwaZuluNatal).Retrievedfromresearchspace.ukzn.ac.za/x mlui/.../Oyowe_Oritsegbube mi_Anthony_2013.pdf

Sandel, M. (1992).The Procedural Republic and the Unencumbered Self.In S. Avineryand A.De-Shalit (Eds.), Communitarianism and Individualism (pp. 23). Oxford: Oxford University Press. 
Ansah \& Mensah: Gyekye's Moderate Communitarianism:...

Sandel, M. (1983).Liberalism and the Limits of Justice. Cambridge: Cambridge University Press.

Taylor, C. (1992a). The Politics of Recognition.In A. Gutmann (Ed.), Multiculturalism and the Politics of Recognition. Princeton: Princeton University Press.

Plato, (2001).The Apology, Phaedo and Crito. (Trans.) Benjamin Jowett. Vol. II. TheHoward Classics. New York: P. F. Collier and Son.

Walzer, M. (1983). Spheres of Justice: A Defense of Pluralism and Equality. Oxford: Basil Blackwell.

Wiredu, K. (1996). Cultural Universals and Particulars: An African Perspective. Indiana University Press: Bloomington. 